\title{
Four Case Reports on Treatment of elevated aminotransferase levels with Herbal medicine containing Artemisia capillaris as Principal Component
}

\author{
Hongmin $\mathrm{Chu}^{1,2 \ddagger}$, Cheol-Hyun Kim ${ }^{1,2 \ddagger}$, Kwang-ho Kim ${ }^{1,2}$, Young-ung Lee ${ }^{1,2}$, \\ Kang-keyng Sung ${ }^{1}$, Sang-kwan Lee ${ }^{1,2^{*}}$ \\ 'Department of Internal Medicine and Neuroscience, College of Korean Medicine, Wonkwang University, \\ Iksan city, Republic of Korea \\ ${ }^{2}$ Department of Korean Internal Medicine, Wonkwang University Gwangju Medical Center, Gwangju city, \\ Republic of Korea
}

\begin{abstract}
Background: Many herbal medications have been used to treat various liver diseases. But the concerns of herbal medicine induced liver injury also existed. In this respect, we would like to report several cases with imporved elevated liver aminotransferase after treating herbal medicine including Artemisia capillaris.

Case Reports: We report four patients with elevated aminotransferase levels (ATLs), which indicate hepatocellular damages. After receiving herbal medicines therapy containing Artemisia capillaris as principal component (HMA), the patients' ATLs were improved. In the first case, the patient's ATLs decreased into normal range after administration of HMA, although they have not been improved with hepatotonics for a long period. In the second case, the patient's ATLs have been elevated after taking anticoagulants. The ATLs were improved with HMA without stopping anticoagulants. In the other two cases, the patients` ATLs were also improved after taking HMA. In addition, there were no changes of previous drugs for treating the corresponding underlying diseases and no adverse events during HMA applications.

Result and Conclusion: The four patients received the herbal medicine containing Artemisia capillaris as principal component and showed improvement of ATLs. These cases suggest that HMA can be considered as alternative or complementary remedies to improve various liver diseases.
\end{abstract}

$\overline{K e y}$ Words : Herbal Medicine, Case Report, Liver disease, Aminotransferase levels, Artemisia capillaris

\section{Background}

In many countries, herbal medicine is used to treat various diseases. Herbal medicine has gained an increasing popularity in the western markets such as USA and Europe. ${ }^{1)}$ For example, in the United States of America (USA), nearly 20\% of adults take herbal products. ${ }^{2)}$ In Asian countries, almost $40 \%$ of the population is reported to take herbal products. ${ }^{3,4)}$ As the usage of herbal medicine

\footnotetext{
- Received : 22 April 2021

- Revised : 14 July 2021

- Accepted : 28 July 2021

- Correspondence to : Sangkwan Lee

Department of Internal Medicine, College of Korean Medicine, Wonkwang University

Iksan, Jeonbuk, 54538, Republic of Korea

Tel : +82-62-670-6412, E-mail : sklee@wku.ac.kr

${ }^{\ddagger} \mathrm{Chu} \mathrm{H}$ and $\mathrm{CH}$ Kim are contributed equally.
} 
increases, concerns about herb-induced liver injry (HILI) and drug-induced liver injury (DILI) also rapidly increase. ${ }^{5,6}$ However, there are several studies that the risk of HILI is low as long as herbal medicines are prescribed by experts or medical doctors. ${ }^{7,89}$ Furthermore, we have also reported some cases with improved ATLs after herbal medicine administration. ${ }^{10,11)}$ These mean that herbal medicine can be safe intervention and have therapeutic effect for liver dysfunction as long as it is prescribed properly. ${ }^{12)}$

In our previous study, we only reported the cases of Injin-Oryongsan single decoction treatment. ${ }^{10,11)}$ We analyzed hospitalized patients` cases who had abnormal value of ATLs and treated with herbal medicine that included Artemisia capillaris as an extension of our previous study.

In the present study, we describe the cases of 4 patients with abnormal ATLs who had been diagnosed with stroke or liver cirrhosis. These patients showed significant improvement in ATLs in short term after the herbal medicine treatment. This study followed the Case Report guidelines (CARE guidelines).

\section{Case Report / Case Presentation}

This study included 4 patients with abnormal levels of aspartate aminotransferase (AST), alanine aminotransferase (ALT), and gamma-glutamyl transferase (r-GTP) in a liver function test who received inpatient treatment from January 2016 to December 2019 at Wonkwang University Gwangju Korean Medical Hospital (WKUGH, Gwangju, South Korea).This study was approved by the WKUGH`s Institutional Review Board (WKIRB
2020-02). We have received informed consent for publication of the case from the 4 patients. The serum aminotransferase level was considered normal in accordance with that used in previous studies. ${ }^{13)}$ The Saeng-Kankunbi-Tang(SKT), Injin -Oryongsan(IJORS), Cheong-Kankunbi-Tang(CKT) decoctions were prepared by boiling in $500 \mathrm{~mL}$ of distilled water for approximately 2 hours until the volume of the solution was concentrated to 100 to $120 \mathrm{~mL}$. Each decoction was administered 3 times daily after meals. The components of herbal decoctions are presented in Table 1.

\section{Case 1.}

A thirty-nine year old man with right hemiparesis who had been diagnosed with internal cerebral hemorrhage at left basal ganglia region on April 25, 2018 and cerebral infarction at left basal ganglia on May 15, 2018 was admitted to WKUGH on May 29, 2018.

Four years before cerebrovascular accident, he underwent cholecystectomy because of the gallstone and had history of alcohol abuse. When the patient was admitted to a general hospital for the first cerebral hemorrhage, abnormal aminotransferase level was observed. An ultrasound procedure was performed to evaluate the liver state, but there was no specific abnormality. A blood test on the day of WKUGH admission showed that his aminotransferase levels were still abnormal. (Figure 1. and Table 2) Although there have been reports of statin-related aminotransferase elevation, the increase in aminotransferase level in this patient was judged to occured by alcohol abuse mainly due to statin had not been used for a while. ${ }^{14)}$ In the particular, there are some reports about Statin-related aminotransferase 
(A)

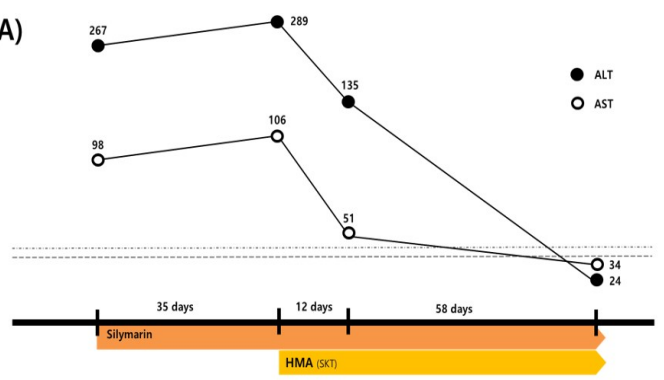

(B)

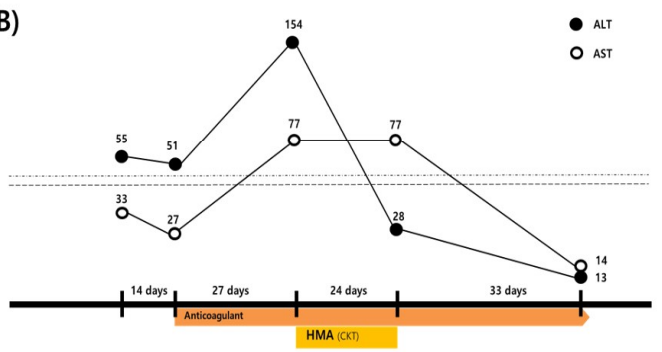

(C)

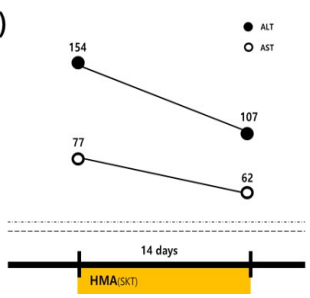

(D)

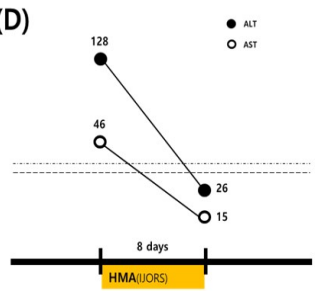

Fig. 1. The Patients' ALTs decrease with taking HMA. The numbers above cicles mean aminotransferase levels. Square boxes represent reference range. Upper and lower dotted line represent normal ALT and AST range. 0-44IU/L and 0-38IU/L respectively.

Abbreviations: HMA,Herbal Medicine containing Artemisia capillaris: SKT,Saeng-Kankunbi-Tang; CKT, Cheong-Kankunbi-Tang; IJORS, Injin-Oryongsan;

elevation, The patient had already taken $140 \mathrm{mg}$ silymarin (Legalon Capsule. 140, Bukwang Pharm, Seoul, Korea) twice a day for abnormal aminotransferase level and other several medications for sequela of cerebral vascular disease such as Aspririn, Telmisartan, Atrovastatin, Alprazolam before he was admitted to WKUGH (Table 3).

WKUGH`s medical staff only performed rehabilitation treatment to patient in consideration of his history and taking multidrug state. The patient was not prescribed additional medication for abnormal aminotransferase level.

On the following blood test performed July 03, 2018, rather, the patient's aminotransferase levels were slightly elevated. Because silymarin didn't improve the aminotransferase levels, WKUGH's medical staff decided to prescribe herbal decoction. The SKT decoction was prescribed three times per day since July 04, 2018 and his aminotransferase levels was followed up after 12 days. After 12 days of herbal medicine treatment, the patient aminotransferase level show significant improvement. A time line of treatment is given in Fig.1(A).

\section{Case 2.}

An 68-year-old man with left hemiplegia who had been diagnosed with cerebral infarction at right middle cerebral artery on December 11, 2018 was admitted to the WKUGH on June 19, 2019. Two years before cerebralvascular accident, he underwent percutaneous coronary intervention and stent insertion on the two coronary arteries.

Because of this cardiac vascular disease history, the patient was taking anti-hypertensive drugs, anti-arteriosclerotic agents and antidiabetic drugs. The patient also suffered from severe diabetes and renal insufficiency, and continued to control the anticoagulant drug in the local general hospital due to persistent abnormalities in coagulation tests like partial thromboplastin time (PTT) or activated partial thromboplastin time (aPTT or APTT).

After admission, WKUGH's medical staff checked an abnormal range of aminotransferase level in a laboratory test of the patient. However the elevated level was mild and patient already 
take multidrugs, (Table 3) we prescribe liver preparations after 1 month follow up. During the follow up period, we found the patient did not take anticoagulant drugs frequently. For his previous cardiac and renal problem, WKUGH's medical staff consulted this problem to general hospital and drug dosage of the patient was adjusted. Take anticoagulant drug regularly, followed up laboratory result showed aminotransferase level were markedly elevated. (Figure 1(B) and Table 2) However the patient should take anticoagulant because of cardiac and renal problem, WKUGH's medical staff maintained whole drug and prescribed CKT. After 2 week of the herbal decoction treatment, the patient aminotransferase levels returned to normal. A time line of treatment is given in Fig.1(B).

\section{Case 3.}

An eighty-one years old woman who had been diagnosed with autoimmune hepatitis and liver cirrhosis (Chuld-Pugh Score class B) in a general hospital was admitted to the WKUGH on October 1, 2016. The chief complain of the patient was whole body itching, and she had already been taking steroids and antihistamines. In the blood test performed on admission date, the aminotransferase levels of the patient was elevated (Figure 1(C) and

Table 1. Components and 1time Dose of Herbal Medicine

\begin{tabular}{|c|c|c|}
\hline & Medical plants & Weight $(\mathrm{g})$ per 1 time \\
\hline \multirow{4}{*}{$\begin{array}{l}\text { HMA1(SKT) } \\
\text { Case 1, Case } 4\end{array}$} & Artemisiae Capillaris Herba (茵蔯蒿), Alismatis Rhizoma (澤瀉) & $15 \mathrm{~g}$ \\
\hline & $\begin{array}{l}\text { Atractylodis Rhizoma Alba (白术), Crataegi Fructus (山査), Hordeum vulgare } \\
\text { (麥芽) }\end{array}$ & $7.5 \mathrm{~g}$ \\
\hline & $\begin{array}{l}\text { Citrus unshiu (陳皮), Poria cocos (获苓), Polyporus umbellatus (猪苓), } \\
\text { Magnoliae Cortex (厚朴) }\end{array}$ & $3.8 \mathrm{~g}$ \\
\hline & $\begin{array}{l}\text { Raphanus sativus (蘿葍子), Aurantii Immaturus Fructus(枳實), Sparganii } \\
\text { Rhizoma (三稜), Zedoariae Rhizoma (蓬术), Citri Unshius Pericarpium } \\
\text { Immaturus (靑皮), Amomi Fructus (砂仁), Glycyrrhiza uralensis (甘草), Zingiber } \\
\text { officinale (生蓄), Agastachis Herba (鹳香) }\end{array}$ & $3 g$ \\
\hline \multirow{4}{*}{$\begin{array}{l}\text { HMA2(CKT) } \\
\text { Case } 2\end{array}$} & Artemisiae Capillaris Herba (茵蔯蒿) & $12 \mathrm{~g}$ \\
\hline & $\begin{array}{l}\text { Puerariae Radix (葛根), Atractylodis Rhizoma Alba (白术), Bupleurum falcatum } \\
\text { (柴胡), Alismatis Rhizoma (澤潟) }\end{array}$ & $6 \mathrm{~g}$ \\
\hline & $\begin{array}{l}\text { Amomi Fructus (砂仁), Raphanus sativus (蘿葍子), Hordeum vulgare (麥芽), } \\
\text { Paeonia lactiflora (芶藥), Crataegi Fructus (山査), Polyporus umbellatus(猪苓), } \\
\text { Poria cocos (获苓), Citrus unshiu (陳皮), Citri Unshius Pericarpium Immaturus } \\
\text { (靑皮), Magnoliae Cortex (厚朴) }\end{array}$ & $3 g$ \\
\hline & $\begin{array}{l}\text { Arecae Pericarpium (大腹皮), Pinellia ternata Breitenbach (牛夏), Zedoariae } \\
\text { Rhizoma (蓬术), Sparganii Rhizoma (三稜), Agastachis Herba (雚香), } \\
\text { Glycyrrhiza uralensis (甘草) }\end{array}$ & $2 \mathrm{~g}$ \\
\hline \multirow{5}{*}{$\begin{array}{l}\text { HMA3(IJORS) } \\
\text { Case } 3\end{array}$} & Artemisiae Capillaris Herba (茵蔯蒿) & $20 \mathrm{~g}$ \\
\hline & $\begin{array}{l}\text { Alismatis Rhizoma (澤瀉), Atractylodis Rhizoma Alba (白术), Polyporus } \\
\text { umbellatus(猪苓), Poria cocos (获苓) }\end{array}$ & $8 g$ \\
\hline & Aurantii Immaturus Fructus(枳實) & $6 \mathrm{~g}$ \\
\hline & Lonicerae Flos (金銀花), Forsythiae Fructus (連䞨) & $4 \mathrm{~g}$ \\
\hline & Coptidis Rhizoma(黃連) & $2 \mathrm{~g}$ \\
\hline
\end{tabular}

SKT;Saeng-Kankunbi-Tang, CKT;Cheong-Kankunbi-Tang, IJORS: Injinoryung-San-Gagambang 
Table 2).

WKUGH's medical staff allowed the patient to keep the medication she had been taking and took IJORS three times a day. After 8 days of IJORS treatment, the patient's aminotransferase levels were improved significantly. A time line of treatment is given in Fig.1(C).

\section{Case 4.}

A fifty-three years old man with right hemiparesis who had been diagnosed with pontine infarction on July 27, 2016 was admitted to WKUGH on August 23, 2016. The patient did not have previous hepatic dysfunction history. But laboratory test results performed on admission date, the patient's aminotransferase levels were abnormal. (Figure 1(D) and Table 2). WKUGH's medical staff maintained drugs prescribed general hospital and prescribed the patient to take SKT three times a day. After 13 days of herbal medicine treatment, the patient aminotransferase levels show significant improvement and returned to normal range. A time line of treatment is given in Fig.1(D).

\section{Discussion}

Herbal medicine has been one of the popular interventions for preventing or treating disease worldwide. $^{1,2,15,16)}$ As the herbal medicine is used frequently, controversial debates about HILI and DILI has also been emerged. ${ }^{5,6)}$ But, several recent researches conducted in the Republic of Korea showed that HILI were rarely occurred and herbal medicine is safe intervention on disease treatment as long as prescribed properly. ${ }^{17,18,19,20)}$ And there are other researches that herbal medicine can

Table 2. Results of Laboratory Test. Comparisons of ATLs and Bilirubin between Administration and Follow Up

\begin{tabular}{|c|c|c|c|c|c|}
\hline Case 1 & $\begin{array}{c}\text { Before SKT } \\
\text { administration }\end{array}$ & $\begin{array}{l}\text { After } 12 \text { days } \\
\text { administration }\end{array}$ & $\begin{array}{l}\text { After } 34 \text { days } \\
\text { administration }\end{array}$ & $\begin{array}{c}\text { After } 70 \text { days } \\
\text { administration }\end{array}$ & Normal range \\
\hline $\mathrm{ALT}(\mathrm{IU} / \mathrm{L})$ & 289 & 135 & 99 & 24 & $5-44$ \\
\hline AST (IU/L) & 106 & 51 & 51 & 34 & $5-44$ \\
\hline $\operatorname{ALP}(\mathrm{IU} / \mathrm{L})$ & 200 & 166.6 & 162.3 & 160 & $40-129$ \\
\hline Bilirubin(Total/Direct) mg/dl & $2.15 / 0.75$ & $0.84 / 0.58$ & $1.79 / 0.74$ & $0.84 / 0.31$ & $0.22-1.2 / 0.05-0.3$ \\
\hline Case 2 & \multicolumn{2}{|c|}{ Before CKT administration } & \multicolumn{2}{|c|}{ After 14 day CKT administration } & Normal range \\
\hline ALT (IU/L) & \multicolumn{2}{|c|}{154} & \multicolumn{2}{|c|}{28} & $5-44$ \\
\hline AST (IU/L) & \multicolumn{2}{|c|}{77} & \multicolumn{2}{|c|}{20} & $5-44$ \\
\hline $\operatorname{ALP}(\mathrm{IU} / \mathrm{L})$ & \multicolumn{2}{|c|}{132.7} & \multicolumn{2}{|c|}{155.6} & $40-129$ \\
\hline Bilirubin(Total/Direct) mg/dl & \multicolumn{2}{|c|}{$0.6 / 0.24$} & \multicolumn{2}{|c|}{$0.52 / 0.19$} & $0.22-1.2 / 0.05-0.3$ \\
\hline Case 3 & \multicolumn{2}{|c|}{ Before SKT administration } & \multicolumn{2}{|c|}{ After 13 day SKT administration } & Normal range \\
\hline $\operatorname{ALT}(\mathrm{IU} / \mathrm{L})$ & \multicolumn{2}{|c|}{253} & \multicolumn{2}{|c|}{107} & $5-44$ \\
\hline AST (IU/L) & \multicolumn{2}{|c|}{116} & \multicolumn{2}{|c|}{62} & $5-44$ \\
\hline $\operatorname{ALP}(\mathrm{IU} / \mathrm{L})$ & \multicolumn{2}{|c|}{790} & \multicolumn{2}{|c|}{764.3} & $40-129$ \\
\hline Bilirubin(Total/Direct) mg/dl & \multicolumn{2}{|c|}{$1.4 / 0.65$} & \multicolumn{2}{|c|}{$1.7 / 0.94$} & $0.22-1.2 / 0.05-0.3$ \\
\hline Case 4 & \multicolumn{2}{|c|}{ Before IJORS administration } & \multicolumn{2}{|c|}{ After 8 day IJORS administration } & Normal range \\
\hline $\operatorname{ALT}(\mathrm{IU} / \mathrm{L})$ & \multicolumn{2}{|c|}{128} & \multicolumn{2}{|c|}{24} & $5-44$ \\
\hline AST (IU/L) & \multicolumn{2}{|c|}{46} & \multicolumn{2}{|c|}{15} & $5-44$ \\
\hline $\operatorname{ALP}(\mathrm{IU} / \mathrm{L})$ & \multicolumn{2}{|c|}{145.5} & \multicolumn{2}{|c|}{160} & $40-129$ \\
\hline Bilirubin(Total/Direct) mg/dl & \multicolumn{2}{|c|}{$1.72 / 0.31$} & \multicolumn{2}{|c|}{$1.19 / 0.22$} & $0.22-1.2 / 0.05-0.3$ \\
\hline
\end{tabular}

ALT, alanine amino transferase; AST: aspartate aminotransferase; ALP : alkaline phosphatase; SKT, Saeng-Kankunbi-Tang; CKT, Cheong -Kankunbi-Tang; IJORS, Injinoryung-San-Gagambang 
improve hepatic disease such as chronic hepatitis, ${ }^{21)}$ alcoholic liver disease, ${ }^{22}$ liver cirrhosis and postoperative liver dysfunctions. ${ }^{23,24)}$ We also reported case report about improvement stroke patient's abnormal ATLs with herbal medicine treatment. ${ }^{25)}$ In our previous research, ${ }^{26)}$ we improved patient's hepatic level without stopping multidrug state, but several limitations existed that some cases treated with combination therapy consisted with herbal medicine and conventional liver preparations and all cases treated one-type herbal medicine named Injin-oryungsan. Thus, in present study, we investigated another cases who treated with various type of herbal medicine which contain Artemisia capillaris for improve ATLs. The patients were treated with herbal decoction that include Artemisia capillaris. 3 times per day for $11.75 \pm 2.28$ (mean \pm standard deviation) day. All the patients' aminotransferase level became lower after treatment. During follow-up period, no

Table 3. Composition of Per Os Medication

\begin{tabular}{|c|c|c|}
\hline Patient & Product name (Ingredients label) & Dosage \\
\hline Case 1 & $\begin{array}{l}\text { Pletal SR Cap. (cilostazol 100mg) } \\
\text { Atorva Tab. } 20 \mathrm{mg} \text { (atorvastatin calcium } 20.73 \mathrm{mg} \text { ) } \\
\text { Twynsta Tab. } 40 / 5 \mathrm{mg} \text { (telmisartan } 40 \mathrm{mg} \text {, amlodipine besylate } 6.935 \mathrm{mg} \text { ) } \\
\text { Alfoatirin soft cap. (choline alfoscerate } 400 \mathrm{mg} \text { ) } \\
\text { Sandoz escitalopram Tab. } 15 \mathrm{mg} \text { (escitalopram oxalate } 15 \mathrm{mg} \text { ) } \\
\text { Nexillen S Tab. (artemisia herb soft extract) } \\
\text { Xanax Tab. } 0.5 \mathrm{mg} \text { (alprazolam } 500 \mu \mathrm{g} \text { ) } \\
\text { Legalon Cap. } 140 \text { (milk thistle extract } 339.4 \mathrm{mg} \text { ) } \\
\text { Exonin CR Tab. (eperisone SR Tab. } 75 \mathrm{mg} \text { ) }\end{array}$ & $\begin{array}{l}2 \mathrm{C} \text { qd } \\
1 \mathrm{~T} \text { qd } \\
1 \mathrm{~T} \text { qd } \\
2 \mathrm{~T} \text { bid } \\
1 \mathrm{~T} \text { SPC } \\
2 \mathrm{~T} \text { bid } \\
0.5 \mathrm{~T} \mathrm{SPC} \\
2 \mathrm{~T} \text { bid } \\
2 \mathrm{~T} \text { bid }\end{array}$ \\
\hline Case 2 & $\begin{array}{l}\text { Aspirin Protect Tab. } 100 \mathrm{mg} \text { (aspirin 100mg) } \\
\text { Cuparin Tab. } 2 \mathrm{mg} \text { (warfarin Sodium 2mg) } \\
\text { Conbloc Tab. } 1.25 \mathrm{mg} \text { (bisoprolol fumarate } 1.25 \mathrm{mg} \text { ) } \\
\text { Furix Tab (furosemide } 40 \mathrm{mg} \text { ) } \\
\text { Lipitor Tab. } 20 \mathrm{mg} \text { (atorvastatin calcium trihydrate } 21.7 \mathrm{mg} \text { ) } \\
\text { Trajenta Tab. (metformin HCl 1000mg, linagliptin } 2.5 \mathrm{mg} \text { ) } \\
\text { Diovan Film Coated Tab. } 80 \mathrm{mg} \text { (valsartan } 80 \mathrm{mg} \text { ) } \\
\text { Lanston LFDT Tab. } 15 \mathrm{mg} \text { (lansoprazole } 15 \mathrm{mg} \text { ) }\end{array}$ & $\begin{array}{l}1 \mathrm{~T} \mathrm{qd} \\
0.75 \mathrm{~T} \text { hs } \\
1 \mathrm{~T} \mathrm{qd} \\
0.5 \mathrm{~T} \mathrm{qd} \\
1 \mathrm{~T} \mathrm{SPC} \\
2 \mathrm{~T} \text { bid } \\
0.5 \mathrm{~T} \mathrm{qd} \\
1 \mathrm{~T} \mathrm{qd}\end{array}$ \\
\hline Case 3 & $\begin{array}{l}\text { Talion Tab. 10mg (bepotastine besilate 10mg) } \\
\text { Methylon Tab. 4mg (methylprednisolone } 4 \mathrm{mg} \text { ) } \\
\text { Ebastel Tab. Boryung (ebastine } 10 \mathrm{mg} \text { ) }\end{array}$ & $\begin{array}{l}2 \mathrm{~T} \text { bid } \\
3 \mathrm{~T} \text { qd, } 1 \mathrm{~T} \\
\text { SPC } \\
1 \mathrm{~T} \text { qd }\end{array}$ \\
\hline Case 4 & $\begin{array}{l}\text { Twynsta Tab. } 40 / 10 \mathrm{mg} \text { (telmisartan } 40 \mathrm{mg} \text {, amlodipine besylate } 13.87 \mathrm{mg} \text { ) } \\
\text { Duvie Tab. } 0.5 \mathrm{mg} \text { (Lobeglitazone sulfate } 0.5 \mathrm{mg} \text { ) } \\
\text { Trajenta-duo Tab. (metformin HCl } 1000 \mathrm{mg} \text {, linagliptin } 2.5 \mathrm{mg} \text { ) } \\
\text { Lipitor Tab. } 40 \mathrm{mg} \text { (atorvastatin calcium trihydrate } 43.4 \mathrm{mg} \text { ) } \\
\text { Plavix Tab. } 75 \mathrm{mg} \text { (clopidogrel Sulfate } 97.875 \mathrm{mg} \text { ) } \\
\text { Dichlozid Tab. (hydrochlorothiazide } 25 \mathrm{mg} \text { ) } \\
\text { Tanamin Tab. } 80 \mathrm{mg} \text { (ginkgo flavon Ext. } 80 \mathrm{mg} \text { ) } \\
\text { Mucosta Tab. (rebamipide } 100 \mathrm{mg} \text { ) } \\
\text { Bonaling-A Tab. (dimenhydrinate } 50 \mathrm{mg} \text { ) } \\
\text { Solondo Tab. (prednisolone } 5 \mathrm{mg} \text { ) } \\
\text { Lyrica Cap. } 75 \mathrm{mg} \text { (Pregabalin } 75 \mathrm{mg} \text { ) } \\
\text { Lacto Well Intestinal Cap. (Bacillus subtilis·streptococcus faecium } 250 \mathrm{mg} \text { ) }\end{array}$ & $\begin{array}{l}1 \mathrm{~T} \text { qd } \\
0.5 \mathrm{~T} \text { qd } \\
2 \mathrm{~T} \text { bid } \\
1 \mathrm{~T} \text { qd } \\
1 \mathrm{~T} \text { bid } \\
0.5 \mathrm{~T} \text { qd } \\
2 \mathrm{~T} \text { bid } \\
2 \mathrm{~T} \text { bid } \\
2 \mathrm{~T} \text { bid } \\
6 \mathrm{~T} \text { qd(prn) } \\
2 \mathrm{~T} \text { bid } \\
2 \mathrm{~T} \text { bid }\end{array}$ \\
\hline
\end{tabular}

Per Os = through the mouth(Latin); BID= Bis in die, same as twice a day; Cap=Capsule; hs= Hora somni, same as before sleep; QD=Quaque die, same as once a day; SPC=supper post cibum, after meals; Tab=Tablet; TID=Ter in die, same as 3 times a day. 
specific adverse effects of the herbal medicine were reported. Especially, Case 1 took liver preparations such as 140mg silymarin (Legalon Capsule, Bukwang Pharm, Seoul, Korea) but elevated ATLs did not improve. Despite maintaining multidrug state, including silymarin, his elevated ATLs began to improve after treated with SKT. It is common for silymarin and SKT to protect liver damage by inhibiting ROS generation. ${ }^{25,26)}$ But SKT has been reported to induce activation of ERK / NRf2 pathway. ${ }^{26)}$ In this respect, SKT may improve the ATLs by acting through a different mechanism of silymarin.

Furthermore, Case 2`s ATLs were elevated after he took warfarin regularly. The patient reported many underlying diseases such as hypertension, diabetes mellitus, prior stroke and underwent stent insertion on coronary artery due to myocardial infarction. For preventing thrombotic events, maintaining anticoagulant drug was important on this case. Therefore, it is meaningful that his hepatic dysfunction improved in a short time after treated with CKT. Liver injury due to warfarin is rare, but there are some cases about anticoagulant -induced liver injury. ${ }^{27)}$ Moreover, warfarin is predominantly metabolite through liver and liver dysfunction is often assumed to be associated with bleeding risk. ${ }^{28,29)}$ Thus, we believe that the recovery normal ATLs through herbal medicine treatment in this case was important for the overall treatment direction of the patient.

The common herb of the prescribed decoction was Artemisia capillaris. Research about Artemisia capillaris showed it contained effective constituents for the treatment of hepatitis such as scoparone, scopoletin, isochlorogenic acid and pumilaside. ${ }^{30)}$
According to traditional Korean medicine classic book such as Dongui-bogam and Dongeuisusebowon, Artemisia capillaris was used for patients with jaundice. $^{31,32)}$ In traditional Korean medicine, as laboratory test couldn't be conducted, jaundice might have been an indication of abnormal hepatic state. Therefore, the herbs used for jaundice in traditional Korean medicine are likely to be applicable to liver diseases. Futhermore, Artemisia capillaris showed effectiveness through Gadd45 mRNA expression, decreasing liver cell aptosis. ${ }^{33)}$

This study has some limitations. First, silymarin stated in these case 1 is difficult to be considered as a first choice for improving ATLs. Therefore, it would be an excessive interpretation that patients who did not improve with western medicines were treated and improved only with herbal medicine. Although, SKT, CKT and IJORS have common with containing artemisa capilaris, SKT is used for Yin Jaundice and CKT, IJORS for Yang Jaundice. Doctors prescribed different prescriptions according to these traditional standards. ${ }^{34)}$ Nevertheless, it is meaningful that case 1 patient's ATLs were clearly improved after the administration of herbal medicine. Second, this study consisted only 4 cases and control group is not included. Third, there is a possibility of bias due to retrospective method. However, the reliability of these cases is not expected to be low, since a clear improvement of abnormal ATLs after herbal medicine treatment has been confirmed, and these cases are consistent with the results of the previous studies. ${ }^{10,24)}$

Despite these limitations, this study suggests the possibility of applying HMA to liver disease. If larger scale and prospective method studies conducted on the same topic in the future, it will 
lead to more specific and clearer conclusions about the potential power of herbal medicine's use of hepatic disease.

\section{CONCLUSION}

In the present study, we report 4 case of improvement aminotransferase levels after treated with herbal medicine consisted with Artemisia capillaris. All 4 patients had lower aminotransferase levels after treatment and no adverse events were reported.

\section{Statement of Ethics}

\section{Statement of Ethics}

The institutional review board (IRB) of Wonkwang University Gwangju Korean medicine hospital approved this case report with a reference number WKIRB 2020-02 on January 23, 2020. The informed consent was obtained from patients for publication of case report.

\section{Conflict of Interest Statement}

The authors declare that they have no conflicts of interest.

\section{Author Contributions}

Chu HM and Kim CH : Writing - Original Draft Kim KH and Lee YY : Resource and Data curation Lim HS : Visualization

Sung KK and Lee SK : Writing - Review and Editing

\section{References}

1. Wegener, T. (2017). Patterns and trends in the use of herbal products, herbal medicine and herbal medicinal products. International Journal of Complementary \& Alternative Medicine. 9(6), 317-319. DOI: 10.15406/ijcam.2017.09.0031

2. Barnes, P. M., Powell-Griner, E., McFann, K., \& Nahin, R. L. (2004). Complementary and alternative medicine use among adults: United States, 2002. Advance data, (343), 1-19.

3. Xu, J., \& Yang, Y. (2009). Traditional Chinese medicine in the Chinese health care system. Health policy (Amsterdam, Netherlands), 90(2-3), 133-139. https://doi.org/10.1016/j.healthpol.2008. 09.003

4. Yoo, TW., Kim, BI., Kim, JB., Kim, DJ., Kim. JW. \& Baik SK. (2007). The survey for the actual condition of drug medication and development of health care cost associated with toxic liver injury in Korean: a multicenter study for the detection and the development of nationwide reporting system of toxic liver injry. Korean J Hepatol, 13(1), 34-43.

5. Ekor M. (2014). The growing use of herbal medicines: issues relating to adverse reactions and challenges in monitoring safety. Frontiers in pharmacology, 4, 177. https://doi.org/10. 3389/fphar.2013.00177

6. Suk, K. T., Kim, D. J., Kim, C. H., Park, S. H., Yoon, J. H. \& Kim, Y. S., et al. (2012). A prospective nationwide study of drug-induced liver injury in Korea. The American journal of gastroenterology, 107(9), 1380-1387. https://doi.org/ 10.1038/ajg.2012.138

7. Kim, N. H., Jung, H. Y., Cho, S. Y., Park, S. 
U., Park, J. M., \& Ko, C. N. (2011). Liver enzyme abnormalities during concurrent use of herbal and conventional medicines in Korea: a retrospective study. Phytomedicine : international journal of phytotherapy and phytopharmacology, 18(14), 1208-1213. https://doi.org/10.1016/j. phymed.2011.06.026

8. Lee, J., Shin, J. S., Lee, Y. J., Kim, M. R., Shin, B. C. \& Lee, J. H. et al., (2019). Battle Over Herb-Induced Liver Injury: Low Prevalence Confirmed through Secondary Evaluation and Research Team's Clarifying Rebuttal to Unwarranted Public Claims. Journal of alternative and complementary medicine (New York, N.Y.), 25(3), 260-264. https://doi.org/10. 1089/acm.2018.0253

9. Cho, J. H., Oh, D. S., Hong, S. H., Ko, H., Lee, N. H. \& Park, S. E., et al., (2017). A nationwide study of the incidence rate of herb-induced liver injury in Korea. Archives of toxicology, 91(12), 4009-4015. https://doi.org/ 10.1007/s00204-017-2007-9

10. Chu H, Park C, Kim C, Sung K, Lee S. Effectiveness and safety of Injinoryung-San -Gagambang (Yinchen Wuling powder) decoctionon stroke patients with elevated serum liverenzymes. Medicine. 2018.97:51 (e13577)

11. Chu, H., Park, C., Kim, C., Sung, K. K., \& Lee, S. (2018). Effectiveness and safety of Injinoryung-San-Gagambang (Yinchen Wuling powder) decoction on stroke patients with elevated serum liver enzymes: Three case reports. Medicine, 97(51), e13577. https://doi.org/ 10.1097/MD.0000000000013577

12. Stickel, F., \& Schuppan, D. (2007). Herbal medicine in the treatment of liver diseases. Digestive and liver disease : official journal of the Italian Society of Gastroenterology and the Italian Association for the Study of the Liver, 39(4), 293-304. https://doi.org/10.1016/j.dld. 2006.11.004

13. Limdi, J. K., \& Hyde, G. M. (2003). Evaluation of abnormal liver function tests. Postgraduate medical journal, 79(932), 307312. https://doi.org/10.1136/pmj.79.932.307

14. Kim, H. S., Lee, S. H., Kim, H., Lee, S. H., Cho, J. H. \& Lee, H., et al. (2016). Statin -related aminotransferase elevation according to baseline aminotransferases level in real practice in Korea. Journal of clinical pharmacy and therapeutics, 41(3), 266-272. https://doi.org/ 10.1111/jcpt. 12377

15. Barnes, P. M., Bloom, B., \& Nahin, R. L. (2008). Complementary and alternative medicine use among adults and children: United States, 2007. National health statistics reports, (12), 1-23.

16. Ye, X. F., \& He, J. (2010). The bright future of Chinese herbal medicine: only after a twisty road. Contemporary clinical trials, 31(6), 508509. https://doi.org/10.1016/j.cct.2010.07.007

17. Lee, W. J., Kim, H. W., Lee, H. Y., \& Son, C. G. (2015). Systematic review on herb-induced liver injury in Korea. Food and chemical toxicology : an international journal published for the British Industrial Biological Research Association, 84, 47-54. https://doi.org/10.1016/ j.fct.2015.06.004

18. Lee, J., Shin, J. S., Kim, M. R., Byun, J. H., Lee, S. Y. \& Shin, Y. S., et al. (2015). Liver enzyme abnormalities in taking traditional 
herbal medicine in Korea: A retrospective large sample cohort study of musculoskeletal disorder patients. Journal of ethnopharmacology, 169, 407-412. https://doi.org/10.1016/j.jep.2015. 04.048

19. Chan, K., Zhang, H., \& Lin, Z. X. (2015). An overview on adverse drug reactions to traditional Chinese medicines. British journal of clinical pharmacology, 80(4), 834-843. https://doi.org/10.1111/bcp.12598

20. Liang, Z., Chen, X., Shi, J., Hu H., Xue Y. \& Ung C.O.L. (2021). Efficacy and safety of traditional Chinese medicines for non-alcoholic fatty liver disease: a systematic literature review of randomized controlled trials. Chin Med, 16(9), 1-38. https://doi.org/10.1186/s13020 $-020-00422-\mathrm{x}$

21. Zhao, C. Q., Zhou, Y., Ping, J., \& Xu, L. M. (2014). Traditional Chinese medicine for treatment of liver diseases: progress, challenges and opportunities. Journal of integrative medicine, 12(5), 401-408. https://doi.org/10.1016/S2095 $-4964(14) 60039-X$

22. Takahashi, H. \& Maruyama, K. (1993). Clinical aspects of Kampo treatment for alcoholic liver disease. Igaku no Ayumi (J Clin Exp Med), 167, 811-814. (in Japanese)

23. Higuchi, K. \& Watanabe, A. (2000). Study on liver cancer-preventive effect of juzentaihoto in patients with liver cirrhosis. Methods Kampo Pharmacol, 5, 29-33. (in Japanese)

24. Okabayashi, T., Mimura, H., Orita, K. (1989). Usefulness of shosaikoto (TJ-9) inthe treatment of postoperative liver dysfunction. Prog Med, 9, 851-855. (in Japanese)
25. Chtourou, Y., Garoui, E., Boudawara, T., \& Zeghal, N. (2013). Therapeutic efficacy of silymarin from milk thistle in reducing manganese-induced hepatic damage and apoptosis in rats. Human \& experimental toxicology, 32(1), 70-81. https://doi.org/10. $1177 / 0960327112455674$

26. Lee, I.W., Choi, H.Y., Lee, J.H., Park, S.D., Kim, S.M. \& Ku, S.K., et al. (2016). Saeng-Kankunbi-Tang (生肝健脾汤) protects liver against oxidative damage through activation of ERK/Nrf2 pathway. Chinese Journal of Integrative Medicine, 22(8), 619-28. https://doi.org/10.1007/s11655-016-2466-5

27. Arora, N., \& Goldhaber, S. Z. (2006). Anticoagulants and transaminase elevation. Circulation, 113(15), e698-e702. https://doi.org/ 10.1161/CIRCULATIONAHA.105.603100

28. Qamar, A., Vaduganathan, M., Greenberger, N. J., \& Giugliano, R. P. (2018). Oral Anticoagulation in Patients With Liver Disease. Journal of the American College of Cardiology, 71(19), 2162 -2175. https://doi.org/10.1016/j.jacc.2018.03.023

29. Harrison M. F. (2018). The Misunderstood Coagulopathy of Liver Disease: A Review for the Acute Setting. The western journal of emergency medicine, 19(5), 863-871. https://doi.org/10.5811/westjem.2018.7.37893

30. Jang, E., Kim, B. J., Lee, K. T., Inn, K. S., \& Lee, J. H. (2015). A Survey of Therapeutic Effects of Artemisia capillaris in Liver Diseases. Evidence-based complementary and alternative medicine : eCAM, 2015, 728137. https://doi.org/10.1155/2015/728137

31. Heo, J. (2009). Donguibogam. Seoul: Bubin PUBLISHERS CO. p142 
32. Lee, J.M.(1964). Dongeuisusebowon. Seoul: Shinil Publishing Co.

33. Kang, W.S., Lee, J.H. \& Wo, H.J. (1999). The effect of Injin and Injinsaryungsangagambang on Liver Cell Viability, Liver Cell Cycle Progression and DNA Damage-induced Apoptosis. J Korean Med, 20(1), 91-105.

34. ANG, P., GIMLAI, D., WANG, L., ZHANG, S., YE, Z. \& LIU, J. et al. (2019). Survival Analysis of Yang Jaundice-Yin-Yang Jaundices-Yin Jaundice Syndrome Differentiation Combined with Western Medicine in the Treatment of Patients with HBV-related
Acute-on-chronic Liver Failure. Journal of Traditional Chinese Medicine, 60(7), 582-586

\section{ORCID}

Hongmin Chu https://orcid.org/0000-0003-0171-0234 Cheol-Hyun Kim https://orcid.org/0000-0001-9533-1117 Kwang-ho Kim https://orcid.org/0000-0002-4561-591X Young-ung Lee https://orcid.org/0000-0001-8657-4950 Kang-keyng Sung https://orcid.org/0000-0003-4050-0977 Sang-kwan Lee https://orcid.org/0000-0001-8674-1712 